\title{
Potensi Kombinasi Bakteri Probiotik Lactobacillus reuteri dengan Sari Buah Kurma (Phoenix dactylifera) sebagai Terapi Penyakit Kanker Kolorektal
}

\author{
Muhammad Luthfi Adnan ${ }^{1}$ \\ ${ }^{\text {I}}$ Program Studi Pendidikan Dokter, Fakultas Kedokteran Universitas Islam Indonesia, Yogyakarta
}

\begin{abstract}
ABSTRAK
Kanker kolorektal merupakan salah satu penyakit keganasan yang paling umum di dunia saat ini. Kanker kolorektal merupakan kasus keganasan paling umum ketiga setelah kanker paru-paru dan payudara serta penyebab kematian paling banyak keempat di dunia. Meskipun penyebab kanker kolorektal belum diktehaui, namun beberapa faktor risiko seperti faktor familial dapat meningkat risiko terkena kanker kolorektal. Penatalaksaan kanker kolorektal sampai saat ini berupa kemoterapi, radioterapi dan terapi bedah. Pemilihan dari terapi tersebut berdasarkan penilaian kolonoskopi, pemeriksaan radiologi barium dengan teknik kontras ganda, CT colonography dan evaluasi histologi. Studi literatur yang dilakukan menunjukkan adanya ekspresi berlebihan dari reseptor histamin dan adanya defisiensi histamin yang memengaruhi terjadinya kanker kolorektal. Bakteri probiotik Lactobacillus reuteri memiliki efek anti kanker dengan memproduksi histamin yang tidak dapat diproduksi sel kanker, sehingga berperan sebagai antiinflamasi. Buah kurma (Phoenix dactylifera) untuk mendukung aktifitas bakteri probiotik dan memiliki efek anti kanker dalam kandungan buah kurma. Penggunaan bakteri probiotik Lactobacillus reuteri dengan sari buah kurma memiliki efek anti kanker kolorektal sehingga berpotensi sebagai terapi dalam pengobatan kanker kolorektal.
\end{abstract}

Kata Kunci: Buah Kurma, Kanker Kolorektal, Lactobacillus reuteri, Probiotik, Terapi

\section{ABSTRACT}

Colorectal cancer is one of the most common malignancies in the world today. Colorectal cancer is the most common malignancy case after lung cancer and cancer as well as the biggest cause of death in the world. Although the cause of colorectal cancer has not been recognized, some risk factors such as family factors can increase the risk of colorectal cancer. Management of colorectal cancer to date is chemotherapy, radiotherapy and surgical therapy. Selection of colonoscopy, barium radiological examination with multiple contrast techniques, CT colonography and histological evaluation. The literature study conducted shows that there are excessive differences in histamine receptors and the presence of histamine deficiencies that affect the increase in colorectal cancer. The probiotic bacteria Lactobacillus reuteri has an anti-cancer effect by producing histamine which cannot be produced by cancer cells, so it works as an anti-inflammatory. Dates (Phoenix dactylifera) to support the activity of probiotic bacteria and have an anti-cancer effect in the content of dates. The use of probiotic bacteria Lactobacillus reuteri with date palm juice has an anti-colorectal cancer effect that is needed as a therapy in the treatment of colorectal cancer.

Keywords: Date Fruit, Colorectal Cancer, Lactobacillus reuteri, Probiotics, Therapy

\section{PENDAHULUAN}

Kanker kolorektal merupakan salah satu penyakit keganasan yang paling umum di dunia saat ini menempati posisi ketiga setelah kanker paru-paru dan payudara serta menjadi penyebab kematian paling banyak keempat di dunia. Kasus kanker kolorektal menyumbang 9\% dari keseluruhan kasus kanker. Pada tahun 
2012, tercatat kasus kanker kolorektal yang mencapai 1,2 juta dengan angka kematian mencapai 700.000 jiwa. Kasus kanker kolorektal diperkirakan akan terus meningkat pada tahun 2030 mencapai 2,2 juta kasus baru dan angka kematian yang mencapai 1,1 juta jiwa. ${ }^{[1]}$

Insidensi tertinggi dari kasus kanker kolorektal berada di Australia dan Selandia Baru (77 per 100.00), Eropa (61,4 per 100.00) dan Amerika Utara (52,8 per 100.000) sedangkan insidensi terendah berada di Afrika (11,6 per 100.000) dan Asia Tengah (12,2 per 100.000). Namun, saat ini sedang terjadi peningkatan insidensi di negara-negara yang pada awalnya memiliki riwayat insidensi kanker kolorektal yang rendah seperti di Asia Barat dan Eropa Timur. ${ }^{[2]}$ Di Indonesia, insiden kasus kanker kolorektal mencapai 34,7 per 100.000 populasi. $^{[3]}$

Kerugian ekonomi yang diakibatkan oleh kanker kolorektal cukup tinggi. Studi yang dilakukan oleh Yabroff et al (2013) mengenai kerugian ekonomi akibat kanker kolorektal di beberapa negara menunjukkan kerugian ekonomi di Amerika Serikatsetiap tahunnya dapat mencapai US\$ 160 juta atau setara dengan lebih dari 2 triliun rupiah. Di Prancis, kerugian ekonomi akibat biaya perawatan kanker kolorektal mencapai $€ 469,7$ juta atau setara dengan lebih dari 8 triliun rupiah sementara di Kanada mencapai US\$187 juta atau setara dengan lebih dari 2,8 triliun rupiah. ${ }^{[4]}$

Penyebab dari kanker kolorektal sampai saat ini masih belum diketahui. Beberapa faktor risiko yang dapat meningkatkan timbulnya kanker kolorektal antara lain faktor genetik seperti riwayat keluarga yang menderita kanker kolorektal, umur, lingkungan, diet dan beberapa kondisi medis seperti kolitis ulseratif dan penyakit Crohn. ${ }^{[5]}$ Konsumsi alkohol, merokok dan daging merah olahan berlebih juga dapat meningkatkan risiko kejadian kanker. Selain itu, kondisi fisik berupa obesitas atau overweight dapat meningkatkan risiko kejadian kanker kolorektal hingga 29\%. ${ }^{[6]}$

Kanker kolorektal umumnya terjadi pada berusia diatas 50 tahun. Namun pada beberapa dekade terakhir telah terjadi peningkatan angka insidensi pada pasien dengan usia 40-44 tahun. ${ }^{[7]}$ Beberapa insidensi kanker kolorektal dapat terjadi sebelum usia 40 tahun karena adanya faktor familial. Risiko faktor familial dapat mengakibatkan kejadian kanker kolorektal mencapai 2,24 kali lipat pada pasien yang memiliki orang tua dengan riwayat kanker kolorektal. ${ }^{[6]}$

Beberapa gejala yang dapat ditimbulkan dari kanker kolorektal yang paling sering terjadi berupa adanya buang air besar (BAB) berdarah dan berlebih, susah $\mathrm{BAB}$, lemah lesu, nyeri perut dan penurunan berat badan. Kejadian BAB berdarah dan berlebih terjadi karena bentuk kanker kolorektal umumnya berupa ulserasi pada rektum, sedangkan pada kejadian susah BAB dikarenakan lesi kanker yang terbentuk di bagian desenden dan sigmoid yang menimbulkan penyempitan lumen karena obstruksi ileum dan penimbunan feses karena konsistensi yang keras. ${ }^{[5]}$

\section{PEMBAHASAN}

\section{Terapi Saat Ini}

Penatalaksaan kanker kolorektal sampai saat ini berupa kemoterapi, radioterapi dan terapi bedah. Pemilihan dari terapi tersebut berdasarkan penilaian kolonoskopi, pemeriksaan radiologi barium dengan teknik kontras ganda, $C T$ colonography dan evaluasi histologi. Pemilihan terapi juga bergantung pada penilaian metasatsis dari sel kanker melalui limfonodi dan dapat bermetastasis ke paru-paru dan hepar. ${ }^{[12,13]}$

Penerapan terapi bedah umumnya dilakukan pada pasien dengan kasus kolorektal non-metastasis. Ukuran lesi kanker juga berpengaruh pada keputusan terapi bedah. Terapi biopsi maupun elektrokoagulasi bipolar kanker kolorektal 
dapat dilakukan bila ukuran kanker $<5$ $\mathrm{mm}$. Pada ukuran kanker yang lebih besar dapat dilakukan tindakan reksisi pada bagian rektum proksimal dan sigmoid. ${ }^{[12,13]}$

Terapi kemoterapi dan radioterapi umumnya digunakan pada kasus kanker stadium lanjut yang telah terdeteksi bermetastasis. Kemoterapi yang diberikan umumnya berupa 5-fluorouracil (5-FU) ditambah oxaliplatin dengan eksisi transanal. Selain penggunaan kemoterapi, penggunaan antibodi monoklonal juga digunakan dalam tatalaksana kanker kolorektal yang telah bermetastasis antara lain bevacizumab, cetuximab dan aflibercept. ${ }^{[12]}$

Berbagai terapi tersebut masih memiliki efek samping yang merugikan. Penggunaan kemoterapi pada penatalaksanaan kanker kolorektal metastasis dapat menimbulkan anemia, leukopenia, neutropenia, diare, mual, muntah dan reaksi hipersensitivitas. Selain itu, pada pemberian antibodi monoklonal juga dapat menimbulkan hipertensi, gangguan hemostasis dan proteinuria. Pada terapi operatif dan radioterapi memiliki kekurangan seperti keterbatasan luas operasi dan tidak efektif pada kanker yang telah bermetastasis. ${ }^{[12]}$

Saat ini, telah diteliti efek pemberian bakteri probiotik terhadap sel kanker kolorektal baik secara in vitro ataupun in vivo. Bakteri probiotik telah diketahui memiliki efek preventif kanker melalui perlindungan mukosa, imunomodulator dan mengurangi paparan karsinogen pencetus terjadinya kanker. ${ }^{[14]}$ Salah satu bakteri probiotik yang telah diteliti memiliki efek antikarsinogenik yaitu Lactobacillus reuteri. ${ }^{[15]} \quad$ Untuk mendukung aktivitas antikarsinogenik dari Lactobacillus reuteri, pemberian kurma (Phoenix dactylifer) juga memberikan efek antikarsinogenik dan dapat berperan sebagai prebiotik bagi Lactobacillus reuteri. ${ }^{[16]}$

\section{Pengaruh Histamin pada Patogenesis Kanker Kolorektal}

Kanker kolorektal memiliki perjalanan patogenesis yang kompleks. Patogenesis dari kanker kolorektal dipengaruhi oleh ketidakstabilan pada kromosom maupun mikrosatelit. ${ }^{[8]}$ Efek dari perkembangan kanker kolorektal dapat ditemukan dengan adanya ekspresi berlebihan dari reseptor histamin berupa reseptor H2. Di sepanjang saluran pencernaan, histamin disintesis dari bentuk L-histidin dengan bantuan enzim histidin dekarboksilase (HDC) dan tersimpan dalam berbagai sel seperti sel mast, sel basofil dan enterochromaffin-like cell (ECL). ${ }^{[9]}$

Enzim HDC diekspresikan oleh sel imatur mieloid sumsum tulang CD11b ${ }^{+}{\text {Ly } 6 G^{+}}^{+}$. Pada sel kanker kolorektal, defisiensi HDC memengaruhi perkembangan abnormal mieloid dan menginduksi karsinogenesis. Defisiensi dari HDC disebabkan dengan adanya hipermetilasi pada situs promotor $\mathrm{CpG}$. Sel imatur mieloid sumsum tulang juga memengaruhi dari produksi Il-6 yang berperan pada angiogenesis dan pertumbuhan tumor. ${ }^{[10]}$ Ekspresi enzim HDC memengaruhi pertumbuhan sel kanker melalui histamine receptor 2 (HR2). Efek promosi dari HR2 dapat menginduksi efek proangiogenik melalui aktivasi vascular endothelial growth factor (VEGF) yang dimediasi oleh enzim siklooksigenase-2 (COX-2). Studi mengenai pengaruh terapi ulkus gaster dan gastro-esophageal reflux disease (GERD) dengan antagonis HR2 menunjukkan adanya efek inhibisi pertumbuhan kanker sehingga berpotensi sebagai penargetanterapi bagi pengobatan kanker kolorektal. $^{[11]}$ 
Potensi Terapi Anti Kanker Kolorektal dengan Bakteri Probiotik Lactobacillus reuteri

Lactobacillus reuteri merupakan bakteri Gram positif yang merupakan bagian dari famili Lactobacillus spp.Lactobacillus spp merupakan salah satu bakteri yang paling sering digunakan sebagai bahan bahan baku produk probiotik saat ini karena memiliki manfaat bagi saluran cerna bila diberikan jumlah yang cukup dan dapat bertahan hidup pada asam lambung.Lactobacillus reuteri merupakan flora normal yang dapat ditemukan pada tubuh seperti pada saluran gastrointestinal, saluran kencing, kulit dan air susu ibu. Bakteri Lactobacillus reuteri juga memiliki kemampuan adaptasi yang baik pada berbagai kondisi $\mathrm{pH}$ dan aktivitas antimikroba pada patogen penyebab kanker kolorektal. ${ }^{[17]}$

Bakteri Lactobacillus reuteri memiliki kemampuan mengolonisasi saluran gastrointestinal karena memiliki kemampuan bertahan pada $\mathrm{pH}$ asam di lambung dan garam empedu pada usus kecil. Bakteri tersebut membentuk suatu biofilm agar dapat bertahan dan mengekspresikan molekul adhesin untuk berikatan pada saluran mukosa gastrointestinal. Pembentukan biofilm oleh bakteri Lactobacillus reuteri selain untuk bertahan hidup juga untuk membentuk koloni dan menginvasi bakteri patogen seperti Escherichia coli. ${ }^{[17]}$

Pada aktivitas anti kanker kolorektal, bakteri Lactobacillus reuteri bekerja melalui produksi histamin yang memengaruhi inflamasi dari sel kanker. Bakteri L. Reuteri memiliki gen krosomal lengkap pembentuk HDC ( $h d c A, h d c B$, dan gen antiporter histidin-histamin $(h d c P))$ sehingga dapat memproduksi histamin yang tidak dapat dihasilkan oleh sel kanker. Pembentukan histamin yang dimodulasi oleh bakteri L. Reuteri berefek pada penghambatan aktivitas sitokin proinflamasi tumor necrosis factor- $\alpha$ (TNF- $\alpha)$, Il-6, Il-22, dan keratinocyte chemoattractant $(\mathrm{KC})$ dan memiliki efek anti tumor (Gambar 1). ${ }^{[18]}$

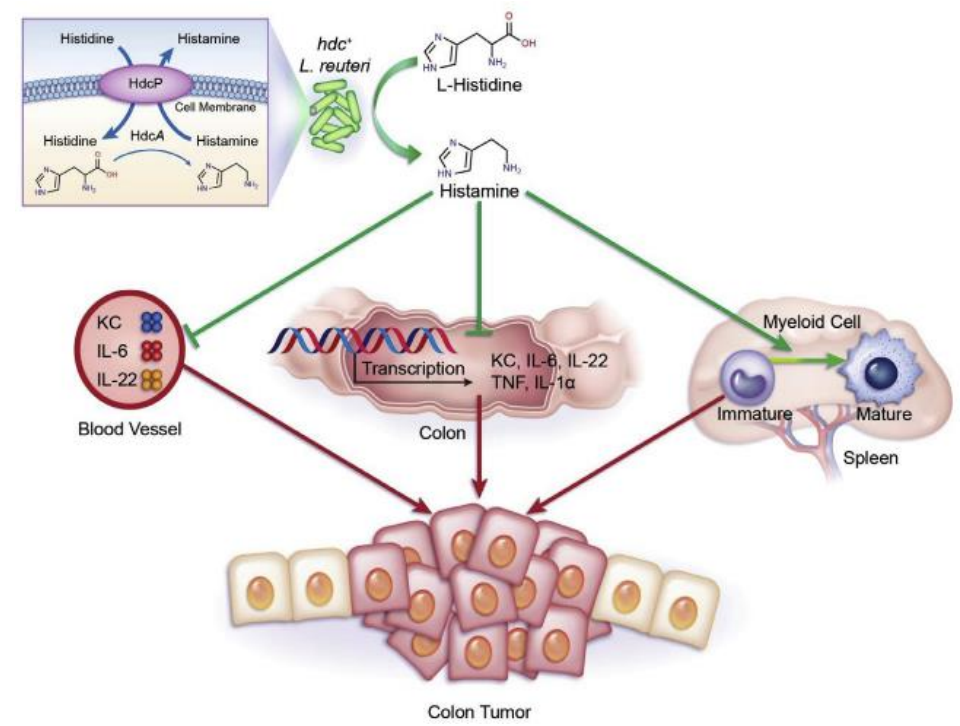

Gambar 1. Mekanisme efek produksi histamin oleh bakteri L. reuteri. ${ }^{[18]}$

Aktivitas produksi histamin dari bakteri L. Reuteri yang dimediasi oleh reseptor HR2 memiliki efek anti inflamasi dengan menekan transkripsi faktor inflamasi dan produksi sitokin proinflamasi. Selain itu, histamin yang diproduksi dari bakteri tersebut dapat bekerja pada maturasi sel mieloid imatur yang berpengaruh pada patogenesis kanker kolorektal. Penelitian yang dilakukan oleh 
Gao et al (2017) menunjukkan efek histamin dari bakteri $L$. reuteri dapat berperan pada aktivitas penghambatan sel kanker kolorektal tikus yang diinduksi dengan azoxymethane (Gambar 2). ${ }^{[18,19]}$

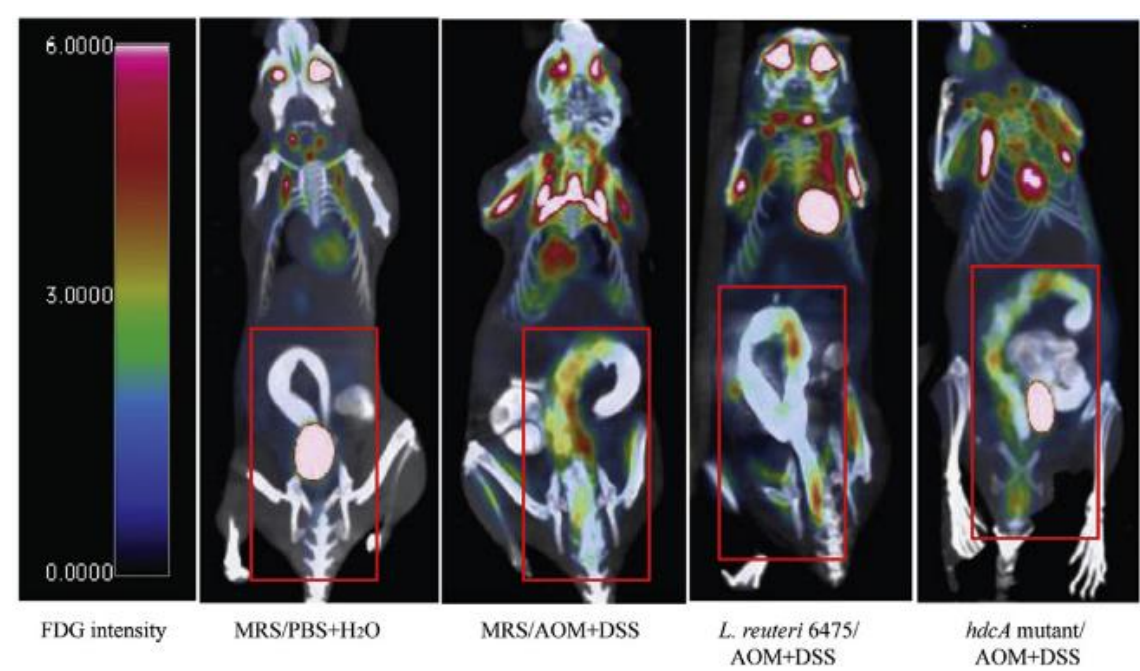

MRS/PBS- $\mathrm{H}_{2} \mathrm{O}$

MRS/AOM-DSS

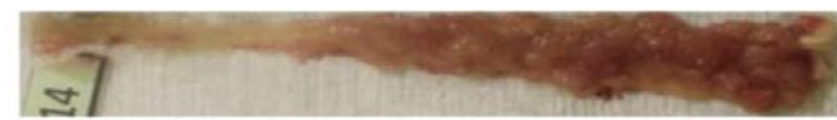

L. reuteri 6475 / AOM-DSS

hdcA mutant / AOM-DSS
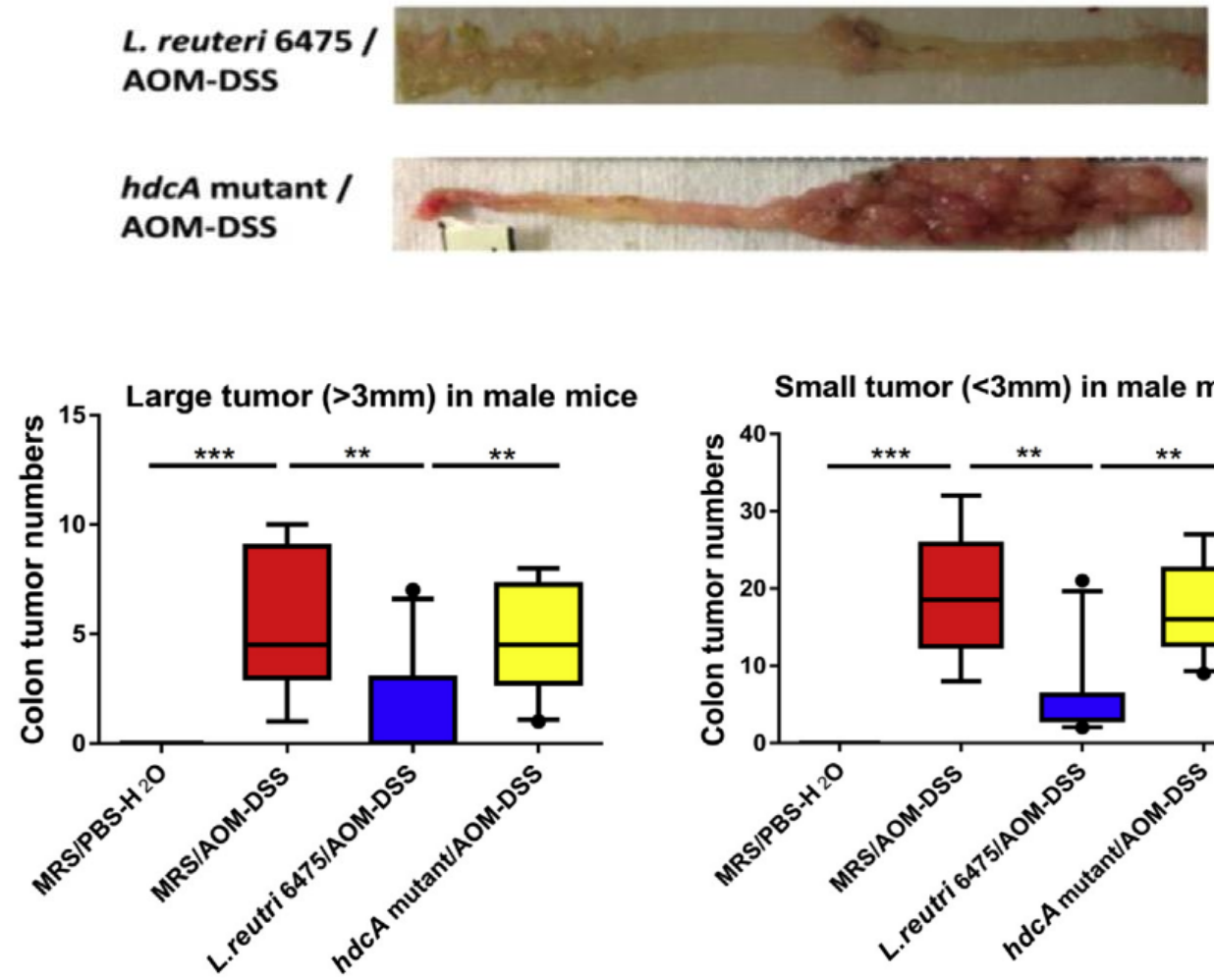

Small tumor $(<3 \mathrm{~mm})$ in male mice

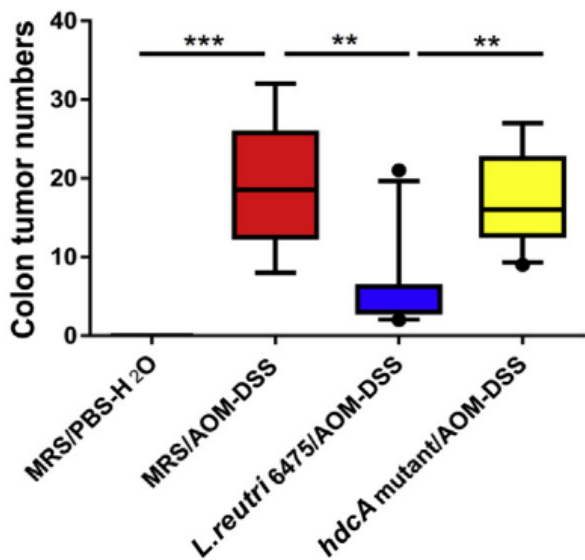

Gambar 2. Efek anti kanker dari bakteri L. Reuteri pada tikus yang diinduksi kanker kolorektal oleh azoxymethane $(\mathrm{AOM}){ }^{[18]}$ 
Selain bekerja melalui produksi histamin, bakteri $L$. reuteri juga bekerja menginduksi apoptosis sel kanker dengan memproduksi rantai lemak asam pendek (short chain fatty acid/SCFA) dengan konsentrasi lebih tinggi dibandingkan bakteri probiotik seperti Lactobacillus rhamnosus dan Lactobacillus acidhophillus (Gambar 3B). Penelitian yang dilakukan oleh Kahouli et al (2016)

\section{Caco-2 + L.r 701359}

A

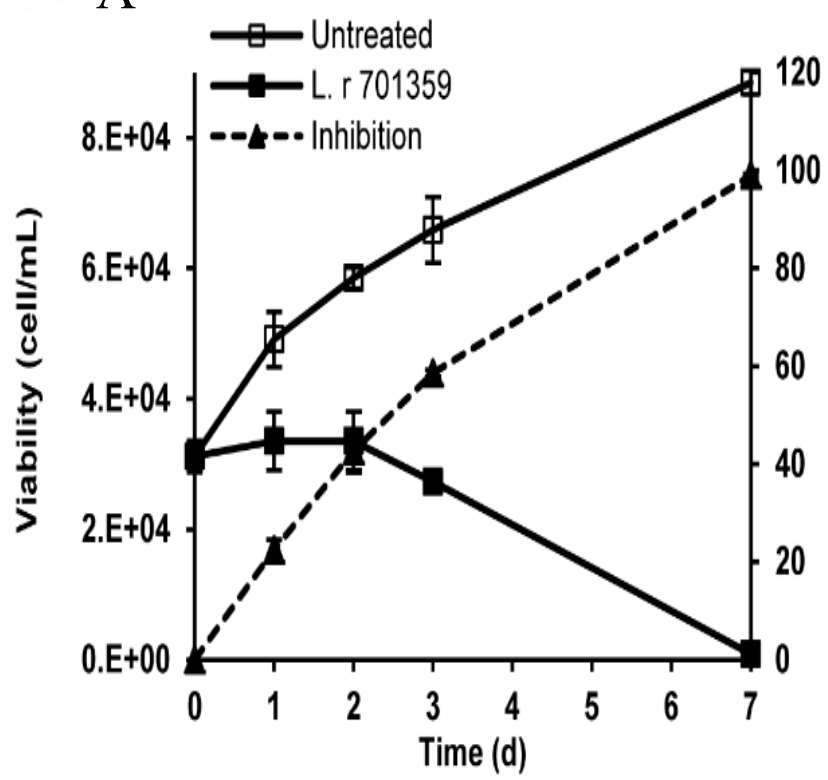

CRL-1831 + L. r 701359

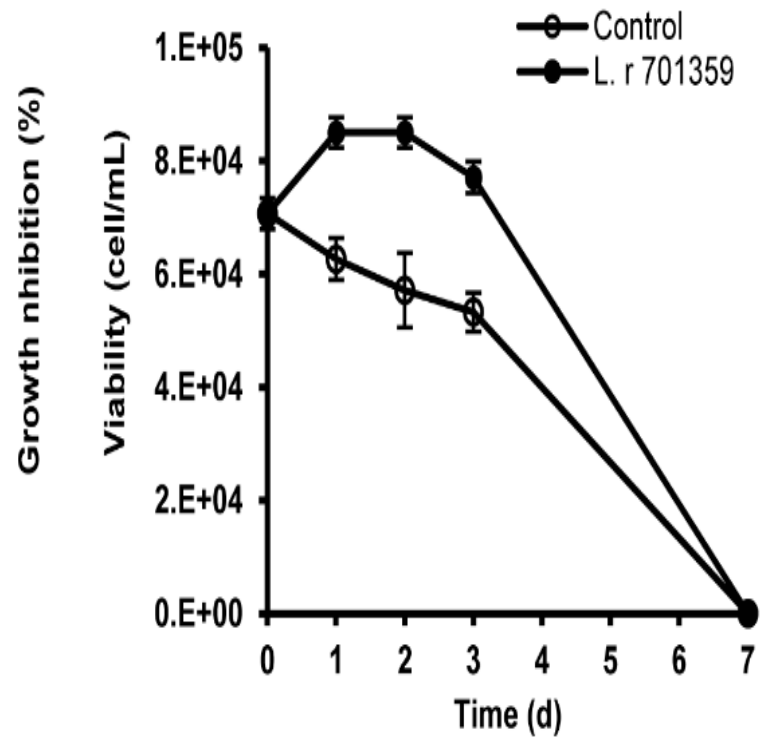

B

\section{Total SCFAs}

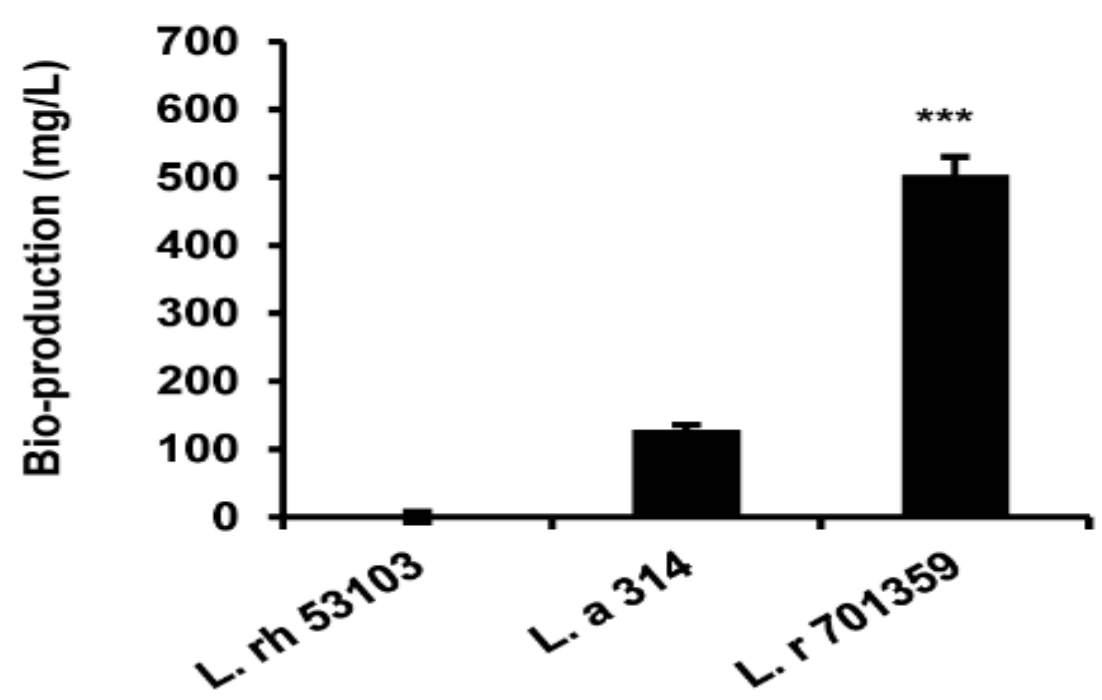

Gambar 3. (A) Pengaruh bakteri L.reuteri pada sel kanker CaCo-2, sel normal kolorektal CRL-1831 dan (B) Perbandingan kandungan SCFA dari bakteri Lactobacillus reuteri, Lactobacillus rhamnosus dan Lactobacillus acidhophillus. ${ }^{[20]}$ 
SCFA yang terdiri dari asetat, propionat dan butirat memiliki sifat sitotoksik pada kandungan asetat dan imunomodulator serta anti inflamasi pada kandungan propionat yang memengaruhi apoptosis sel kanker namun memiliki efek samping yang rendah pada sel normal. Selain itu, L. reuteri mampu menginduksi proliferasi sel sehat pada kolon sehingga memiliki kemampuan meningkatkan keehatan saluran gastrointestinal. ${ }^{[20]}$

Untuk meningkatkan potensi bakteri probiotik L. reuteri, diperlukan komponen yang dapat membantu pertumbuhan bakteri yaitu berupa media prebiotik. Media prebiotik yang digunakan merupakan senyawa yang tidak tercerna yang dapat dimetabolisme oleh mikroorganisme di kolon, memodulasi komposisi mikrobioma dan memberikan efek fisiologis yang baik bagi tubuh. Salah satu media prebiotik yang dapat mendukung aktivitas bakteri probiotik dan memiliki efek fisiologis yang baik adalah kurma (Phoenix dactylifera). ${ }^{[21]}$

Potensi Sari Buah Kurma (Phoenix dactylifera) sebagai Prebiotik dan Anti Kanker Kolorektal

Buah Kurma (Phoenix dactylifera) merupakan buah yang berasal dari daerah Timur Tengah dan Afrika Utara dan bagian dari famili Arecaceae. Buah kurma telah dibudidayakan sejak zaman kuno dan telah menjadi makanan pokok dari masyarakat lokal karena kemampuan adaptasi di lingkungan gurun. ${ }^{[22]}$ Kurma telah diteliti karena memiliki nilai farmakologis sebagai terapi hipotensi, hipoglikemik, hepatoprotektif dan anti diare. Kandungan serat pada kurma yang tinggi $(6,4-11,5 \%)$ dapat berperan sebagai sumber karbon dari fermentasi bakteri probiotik. ${ }^{[23]}$

Kandungan serat dari kurma yang mengandung arabinose, xylose, galaktosa, dan mannan memiliki manfaat untuk menstimulus pertumbuhan dan aktivitas bakteri $L$. reuteri. ${ }^{[24]}$ Serat yang difermentasi oleh bakteri meningkatkan produksi SCFA yang dihasilkan oleh bakteri $L$. reuteri. Efek dari serat yang mampu meningkatkan produksi SCFA dapat meningkatkan aktivitas sitotoksik sel kanker dari kandungan SCFA dan mempromosikan sel-sel sehat dari epitel usus. $^{[25]}$

Kandungan serat dari kurma tersebut dapat berperan sebagai pengganti media pertumbuhan bakteri $L$. reuteri media tumbuh standar DeMan Rogosa Sharp (MRS). Penelitian yang dilakukan oleh Ayad et al (2016) menunjukkan tidak ada perbedaan waktu pertumbuhan dan jumlah bakteri L. reuteri pada media MRS dengan media kultur kurma yang ditambah dengan phytone peptone (PP) 0,8\% (Gambar 4B). Selain itu, penggunaan kurma sebagai media tumbuh bakteri $L$. reuteri lebih ekonomis dibandingkan media MRS sehingga kurma dapat berpotensi sebagai pengganti media pertumbuhan bakteri L. reuteri (Gambar $4 \mathrm{~A}) \cdot{ }^{[16]}$

\begin{tabular}{lccc}
\hline Growth Medium & \multicolumn{3}{c}{ Lactobacillus reuteri Strains } \\
\hline & DSM 20016 & CF2-7F & SD 2112 \\
\hline MRS (Standard) & $7.89 \pm 0.02$ & $7.84 \pm 0.02$ & $7.86 \pm 0.01$ \\
CONTROL & $3.54 \pm 0.1$ & $3.55 \pm 0.1$ & $3.57 \pm 0.1$ \\
DPM+0.2PP & $4.55 \pm 0.0$ & $4.48 \pm 0.0$ & $3.51 \pm 0.0$ \\
DPM+0.4PP & $4.65 \pm 0.1$ & $4.52 \pm 0.1$ & $4.34 \pm 0.0$ \\
DPM+0.6PP & $6.63 \pm 0.1$ & $6.68 \pm 0.0$ & $6.69 \pm 0.0$ \\
DPM+0.8PP & $7.00 \pm 0.1$ & $6.93 \pm 0.0$ & $6.91 \pm 0.0$ \\
\hline
\end{tabular}




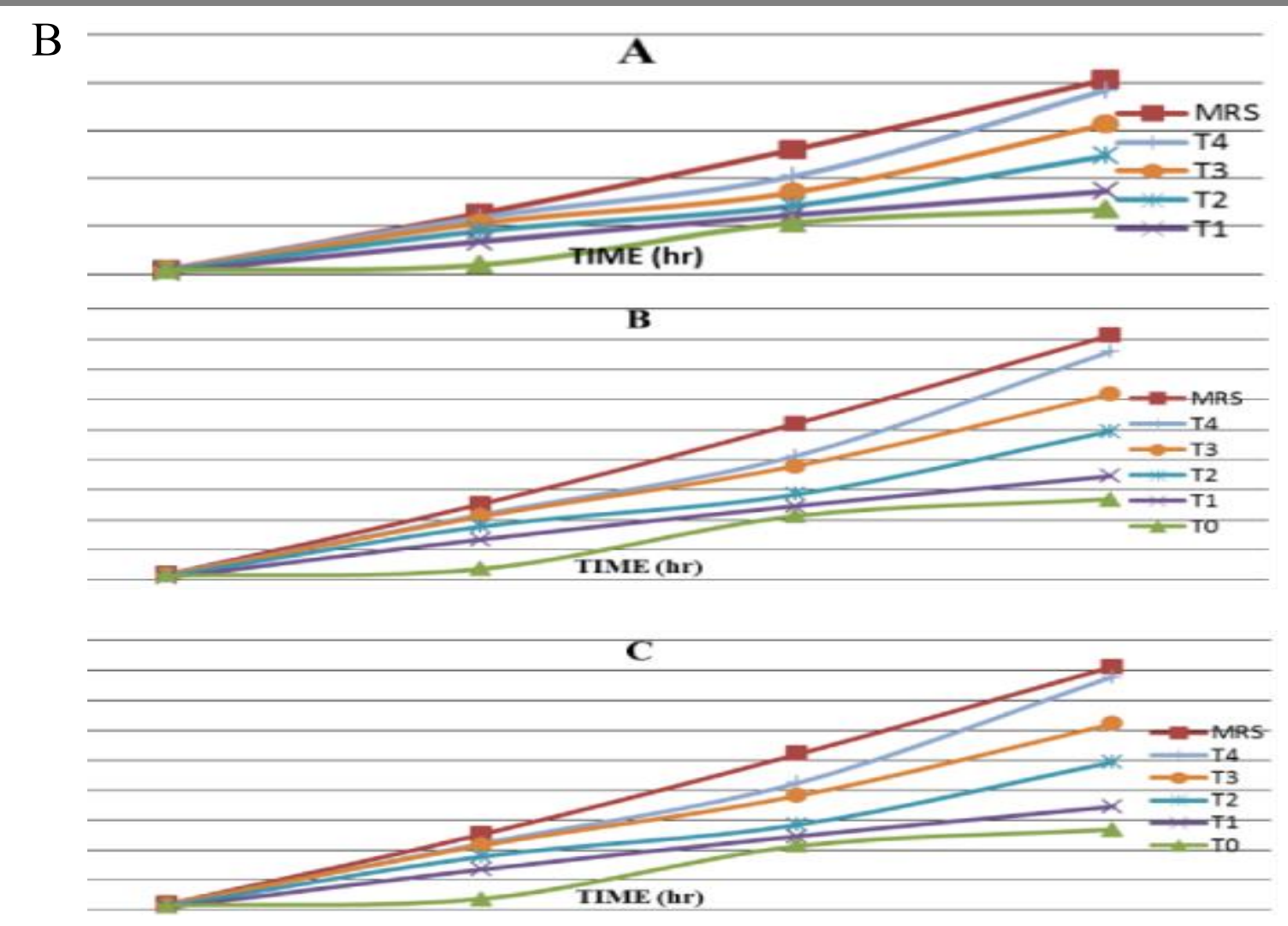

Gambar 4. (A) Jumlah tiga strain bakteri L. reuteri dengan kurma dan PP 0,2\% (T1). 0,4\% (T2), $0,6 \%$ (T3) dan $0,4 \%$ (T4) dan (B) Perbandingan waktu pertumbuhan. ${ }^{[16]}$

Buah kurma juga memiliki aktivitas inhibitor sel kanker yang tinggi. Penelitian yang dilakukan Eid et al (2014) menunjukkan aktivitas konsumsi ekstrak kurma dapat menginhibisi sel kanker CaCo-2 lebih tinggi dibandingkan dengan ekstrak polifenol kurma saja. Kandungan dalam kurma yang berperan sebagai anti proliferasi sel kanker antara lain asam
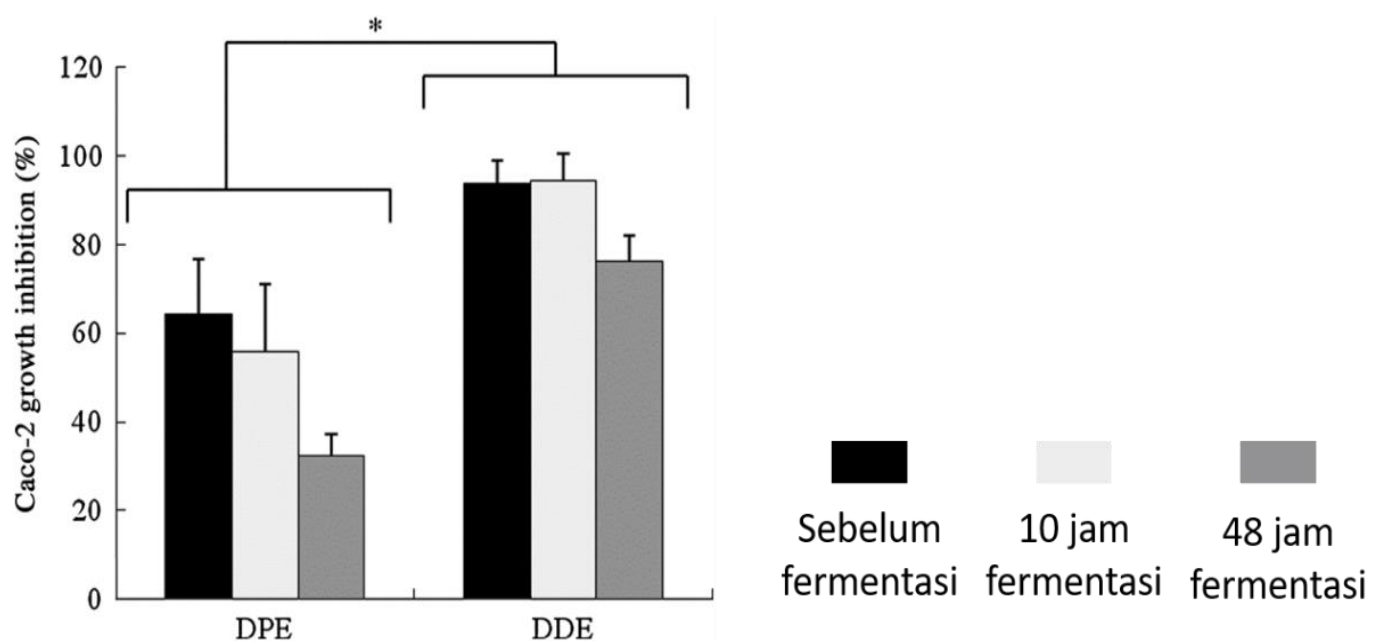

fenolik, flavonoid, dan antosianin lebih berperan dalam inhibisi sel kanker dibandingkan konsumsi polifenol saja dari ekstrak kurma. Aktivitas inhibisi sel kanker oleh buah kurma menurun setelah fermentasi karena asam fenolik dan senyawa lainnya yang hilang saat ada di kolorektal (Gambar 5). ${ }^{[26]}$

Gambar 5. Perbandingan aktivitas inhibisi sel kanker Caco-2 oleh Date Polyphenol Extract (DPE) dan Digested Date Extract (DDE). ${ }^{[26]}$ 


\section{KESIMPULAN}

Kanker kolorektal merupakan salah satu kanker yang paling banyak. Terapi pengobatan kanker kolorektal sampai saat ini masih belum efektif. Efek samping yang ditimbulkan dari terapi saat ini masih memiliki dampak yang merugikan bagi manusia. Saat ini, penelitian mengenai aktivitas bakteri probiotik Lactobacillus reuteri menunjukkan adanya potensi sebagai terapi anti kanker kolorektal.

Pada sel kanker kolorekral, terjadi defisieni gen enzim penghasil asam amino histamin yaitu histidin dekarboksilase (HDC). Bakteri L. reuteri memiliki kemampuan untuk memproduksi histamin yang tidak dapat dihasilkan oleh sel kanker sehingga mampu menginduksi apoptosis sel kanker.

Untuk mendukung aktivitas bakteri probiotik $L$. reuteri, diperlukan suatu senyawa prebiotik yang dapat mendukung aktivitas bakteri. Salah satu senyawa prebiotik yang dapat mendukung aktivitas bakteri probiotik adalah kurma (Phoenix dactylifera). Selain dapat mendukung aktivitas bakteri $L$. reuteri, buah kurma juga memiliki efek menginhibisi sel kanker karena memiliki kandungan asam fenolik, flavonoid, dan antosianin.

\section{SARAN}

Tantangan penggunaan kombinasi bakteri probiotik Lactobacillus reuteri dengan buah kurma adalah belum adanya pengujian secara in vivo pada kombinasi keduanya sehingga belum diketahui bagaimana efek samping yang ditimbulkan oleh kombinasi tersebut. Selain itu, penelitian lebih lanjut diperlukan untuk mengetahui dosis efektif dari kombinasi bakteri Lactobacillus reuteri dan buah kurma untuk terapi kanker kolorektal sehingga potensi penggunaan kombinasi bakteri probiotik Lactobacillus reuteri dengan buah kurma dapat dikembangkan menjadi terapi kanker di masa depan.

\section{DAFTAR PUSTAKA}

[1] Arnold M, Sierra MS, Laversanne M, Soerjomataram I, Jemal A, Bray F. Global patterns and trends in colorectal cancer incidence and mortality. Gut. 2017;66(4):683-91.

[2] Torre LA, Bray F, Siegel RL, Ferlay J. Global Cancer Statistics, 2012. CA Cancer J Clin. 2015;65(2):87-108.

[3] Abdullah M, Sudoyo A, Utomo A, Fauzi A, Rani A. Molecular profile of colorectal cancer in Indonesia: is there another pathway? Gastroenterol Hepatol From Bed to Bench. 2012;5(2):71-8.

[4] Yabroff KR, Borowski L, Lipscomb J. Economic studies in colorectal cancer: Challenges in measuring and comparing costs. J Natl Cancer Inst Monogr. 2013;(46):62-78.

[5] Hamdi M, Zahari A. Profil Karsinoma Kolorektal di Laboratorium Patologi Anatomi Fakultas Kedokteran Universitas Andalas Priode Januari 2009 sampai Desember 2011. J Kesehat Andalas [Internet]. 2015;4(2):398-403. Available from: http://jurnal.fk.unand.ac.id/index.php/j $\mathrm{ka} /$ article/viewFile/261/250

[6] Johnson CM, Wei C, Ensor JE, Smolenski DJ, Christopher I, Levin B, et al. Meta-analyses of Colorectal Cancer Risk Factors Constance. Cancer Causes Control [Internet]. 2014;24(6):1207-22. Available from: http://www.ncbi.nlm.nih.gov/pubmed/ 23563998\%0Ahttp://www.pubmedcen tral.nih.gov/articlerender.fcgi?artid $=\mathrm{P}$ MC4161278

[7] Hadjipetrou A, Anyfantakis D, Galanakis CG, Kastanakis M, Kastanakis S. Colorectal cancer, screening and primary care: A mini literature review. World J Gastroenterol. 2017;23(33):6049-58.

[8] Pritchard C, Grady W. Colorectal Cancer Molecular Biology Moves Into Clinical Practice. Gut. 2011;60(1):116-29. 
[9] Coruzzi G, Adami M, Pozzoli C. Role of histamine $\mathrm{H} 4$ receptors in the gastrointestinal tract. Front Biosci (Schol Ed). 2012;Jan(4):226-39.

[10] Yang XD, Ai W, Asfaha S, Bhagat G, Friedman RA, Jin G, et al. Histamine deficiency promotes inflammationassociated carcinogenesis through reduced myeloid maturation and accumulation of $\mathrm{CD} 11 \mathrm{~b}+\mathrm{Ly} 6 \mathrm{G}+$ immature myeloid cells. Nat Med. 2011;17(1):87-95.

[11]Losurdo G, Principi M, Girardi B, Pricci M, Barone M, Ierardi E, et al. Histamine and histaminergic receptors in colorectal cancer: From basic science to evidence-based medicine. Anticancer Agents Med Chem. 2018;18(1):15-20.

[12]Panduan Penatalaksaan Kanker Kolorektal. Jakarta; 2014.

[13] Sudoyo A, Setiyohadi B, Alwi I, Simadibrata M. Buku Ajar Ilmu Penyakit Dalam. Edisi VI. Jakarta: InternaPublishing; 2014.

[14] Kahouli I, Tomaro-Duchesneau C, Prakash S. Probiotics in colorectal cancer (CRC) with emphasis on mechanisms of action and current perspectives. J Med Microbiol. 2013;62(PART8):1107-23.

[15]Zhong L, Zhang X, Covasa M. Emerging roles of lactic acid bacteria in protection against colorectal cancer. World J Gastroenterol. 2014;20(24):7878-86.

[16] Ayad AA, El-rab DG, Shahbazi A, Worku M, Schimmel K, Zimmerman T. Using Date Palm ( Phoenix dactylifera L .) by-products to Cultivate Lactobacillus reuteri spp . J Food Res. 2016;5(5):77-81.

[17] Mu Q, Tavella VJ, Luo XM. Role of Lactobacillus reuteri in human health and diseases. Front Microbiol. 2018;9(APR):1-17.

[18] Gao C, Ganesh BP, Shi Z, Shah RR, Fultz R, Major A, et al. Gut MicrobeMediated Suppression of Inflammation-Associated Colon
Carcinogenesis by Luminal Histamine Production. Am J Pathol [Internet]. 2017;187(10):2323-36. Available from: http://dx.doi.org/10.1016/j.ajpath.2017 .06 .011

[19]Gao C, Major A, Rendon D, Lugo M, Jackson V, Shi Z, et al. Histamine H2 receptor-mediated suppression of intestinal inflammation by probiotic lactobacillus reuteri. MBio. 2015;6(6):1-12.

[20]Kahouli I, Handiri NR. Characterization of L. reuteri NCIMB 701359 Probiotic Features for Potential Use as a Colorectal Cancer Biotherapeutic by Identifying Fatty Acid Profile and Anti-Proliferative Action against Colorectal Cancer Cells. Drug Des Open Access [Internet]. 2016;5(2). Available from: http://www.omicsgroup.org/journals/c haracterization-of-1-reuteri-ncimb701359-probiotic-featuresforpotential-use-as-a-colorectalcancer-biotherapeutic-by-identifyin2169-0138-1000131.php?aid $=76188$

[21]Althubiani AS, Al-Ghamdi SB, Samreen, Qais FA, Khan MS, Ahmad I, et al. Plant-Derived Prebiotics and Its Health Benefits [Internet]. New Look to Phytomedicine. Elsevier Inc.; 2019. 63-88 p. Available from: https://linkinghub.elsevier.com/retriev e/pii/B9780128146194000045

[22]ABD RABOU AFN. The current status of the date palm (Phoenix dactylifera) and its uses in the Gaza Strip, Palestine. Biodiversitas, J Biol Divers [Internet]. 2017;18(3):104761. Available from: http://biodiversitas.mipa.uns.ac.id/D/ D1803/D180324.pdf

[23] Mallhi T, Qadir M, Ali M, Ahmad B, Khan Y, Rehman A. Ajwa Date (Phoenix dactylifera): An Emerging Plant in Pharmacological Research. Pak J Pharm Sci. 2014;27(3):607-16.

[24] Mrabet A, Rodríguez-Arcos R, Guillén-Bejarano R, Chaira N, 
Ferchichi A, Jiménez-Araujo A. Dietary fiber from Tunisian common date cultivars (Phoenix dactylifera L.): Chemical composition, functional properties, and antioxidant capacity. J Agric Food Chem. 2012;60(14):365864.

[25] Slavin J. Fiber and prebiotics: Mechanisms and health benefits. Nutrients. 2013;5(4):1417-35.
[26] Eid N, Enani S, Walton G, Corona G, Costabile A, Gibson G, et al. The impact of date palm fruits and their component polyphenols, on gut microbial ecology, bacterial metabolites and colon cancer cell proliferation. J Nutr Sci [Internet]. 2014;3(22):e46. Available from: http://www.journals.cambridge.org/ab stract_S2048679014000160 